\title{
Local administrative capacity based on the presence of expert staff in municipal city halls and inter-municipal cooperation entities
}

\author{
Eva Marín Hlynsdóttir, Associate Professor, Faculty of Political Science, \\ University of Iceland
}

\begin{abstract}
Local government in Iceland has been through extensive functional reforms in the past three decades. Territorial reforms have been less successful even though the central government has openly aimed to enhance the capacity of the local governments. This study aims to estimate the administrative capacity of Icelandic local governments by estimating the level of expertise in the tasks of planning, education and social service. The findings show that there is a considerable difference with respect to size, as municipalities with more than 3,000 citizens have much higher levels of expertise in comparison to smaller municipalities. The municipalities are only partially able to turn to inter-municipal cooperation (IMC) for compensation because the municipalities in more densely populated areas are more likely to set up IMC entities than those in more sparsely populated areas. The municipalities in less populated areas are also more likely to buy their services from private service providers. Moreover, the smallest municipalities have transferred a large bulk of their functions to other municipalities through contracting. The findings suggest that IMCs may not be the best answer for small municipalities, especially those in rural and remote areas.
\end{abstract}

Keywords: Administrative capacity; municipal size; inter-municipal cooperation (IMC). 


\section{Introduction}

In the European context, decentralisation and devolution of tasks from the state to the local level have been a driving force behind local-level reforms in the past few decades (Kuhlmann \& Bouckaert 2016; Kuhlmann \& Wollmann 2014). This has been especially noticeable in the case of the Nordic countries in which reorganisation has been driven by a subsidiary principle, resulting in a highly decentralised administrative structure with both politically and functionally strong local governments (Baldersheim, Rose, \& Sandberg 2017). However, there are some internal differences within the Nordic model, for example, the Icelandic welfare system developed in a slightly different way from that of other Nordic countries, particularly regarding the local state relationship. The Icelandic local governments share of the total public expenditure is roughly 30 per cent, which is considerably lower than in other Nordic countries, and before 1990 the Icelandic local governments had a very small role in the provision of welfare services. This has since changed, as local authorities are now responsible for a multitude of services e.g. in pre-school and primary school education, social services ${ }^{1}$ and disability services. Furthermore, they are also responsible for tasks such as waste management and planning (Hlynsdóttir 2018a).

As the role of local authorities has grown in the provision of welfare services, the questions regarding the purpose of local government in relation to democracy and efficiency have become even more important (Denters, Goldsmith, Ladner, Mouritzen, \& Rose 2014) and Iceland is not an exception to that rule. Thus, the issue of consolidation versus fragmentation of local government has become highly relevant and has greatly influenced public debate (Hlynsdóttir 2018a; Eythórsson 2014). There is a robust body of research available on various types of local reforms in the international setting (Askim, Klausen, Vabo, \& Bjurstrom 2016; Bel \& Gradus 2018; Feiock 2007; Hulst \& Montfort 2007; Tavares 2017; Teles 2016). In the Icelandic context, there is substantial research available on the issue of consolidation (Eythórsson 2014), while less is known about inter-municipal cooperation (IMC) (Eythórsson 2018; Eythórsson, Kettunen, Klausen, \& Sandberg 2018). However, there is limited information on the issue of local administration (Kristinsson 2001, 2014) and the level of service provision or the level of personnel (Hlynsdóttir 2016; Kristinsson 1994) at the Icelandic municipal level.

Strengthening the local level or, as it is often defined, 'enhancing its capacity', has been on the Icelandic national government's agenda since the early 1990s (Eythórsson 2012). To achieve this, top-down-driven amalgamation schemes were initiated in 1993 and 2005, although with limited results. The main reason for this is that amalgamation is by default voluntary, as the Local Government Act no. 138/2011 states that citizens must be allowed a binding referendum on proposed amalgamation schemes. Therefore, although the state has successfully decentralised welfare services, which has resulted in a large-scale voluntary municipal merger, this has happened in an unplanned and unregulated way (Hlynsdóttir 2018a). Although the number of municipalities went from a whopping 204 municipalities in 1990 down to 76 in 2006, the Icelandic local government system is still highly fragmented, with 39 municipalities with less than 1,000 
citizens and 25 that have less than 500 citizens out of 72 municipalities in 2018. As all municipalities are obliged to deliver the same level of services by law, this sheds light on problems relating to how local authorities solve the obvious lack of economy of scale. The aim of this paper is to explore the capacity of the Icelandic local administration to provide expert services in education, social services and planning, based on the size of 'permanent administration' (Polidano 2000) and on the scope of inter-municipal cooperation. The paper aims to answer the following three research questions:

- How big is the permanent machinery of the Icelandic local government administration?

- What expertise is present in the city hall for planning, education and social services?

- How do municipalities compensate if lacking in expertise in the city hall?

The paper begins by theoretically situating the study and then moves on to the method and data section. The subsequent chapter shortly discusses inter-municipal cooperation in Iceland, followed by a chapter that concentrates on the results and discusses the findings. The paper then concludes with a short conclusion.

\section{Theoretical arguments}

\subsection{The optimal size of government}

Kuhlmann and Wollmann (2014) point out that there are both pros and cons to decentralisation in relation to various dimensions of administrative reforms, such as effectiveness. Thus, while decentralisation does increase the proximity to citizens, an old rationale for local government, advocated by Mill (in Sharpe 1970), it also decreases specialisation and may increase political interference in policy implementation. Vries (2000) argues that decentralisation is a relative concept closely linked to the contested issue of 'optimal' size. In general, researchers agree that there is no optimal size of government and that different sizes fit different tasks (Feiock 2007).

Size is a highly contested concept in the literature on local government. Dahl and Tufte (1973) argue, in their seminal work Size and Democracy, that size is a two-dimensional concept. On the one hand, there is citizen effectiveness and, on the other, system capacity. The former refers to the extent to which the citizens can control the decisions of the polity, while the latter refers to the capacity of the polity to respond adequately to its citizens. Both dimensions have been used to argue for and against large-scale amalgamation (Baldersheim \& Rose 2010), as it has been argued that local authorities in smaller municipalities are more responsive to their citizens demands, while larger municipalities are better equipped with a larger administration and are consequently able to provide better services. Emphasis on the responsiveness of local officials has been obvious in the rhetoric supporting the case of preserving the existence of very small municipalities (Denters et al. 2014; Kristinsson 2014). Those in favour of a fragmented system have mostly turned towards public choice theory for empowering arguments (Baldersheim 
\& Rose 2010; Feiock 2007), supporting the notion of small municipalities being just as capable of providing their citizens with adequate living standards as large municipalities. The main argument has been that collaboration or shared services are an excellent way to provide citizens with services while, at the same time, keeping a fragmented system in place (Teles 2016; Warner 2015). Baldersheim and Rose (2010) argue for a classification of the problems of scale using the terms 'up-scaling', 'down-scaling' and 'trans-scaling'. The first solution to the problems of scale is to consolidate or transfer functions to regions or counties, while the second is in favour of fragmentation and the transference of tasks on to the lower levels of government. The third solution views collaboration or cooperation at the local level as a special reform path, when, for example, countries enable their local government to set up shared services. In general, the Nordic countries are believed to be more inclined to use the 'up-scaling' approach, while the Southern European countries are more inclined towards the 'trans-scaling' one in order to enable very small municipalities to exist, substituting large-scale territorial reforms (Kuhlmann \& Wollmann 2014). One of the main arguments in the Icelandic debate on enhancing the local government capacity centres around strengthening its professional or administrative capacity, mostly by stating that through merging smaller municipalities into larger units an increase in administrative capacity would automatically follow (Eythórsson 2012). However, limited attention has been given to clarifying the concept of administrative capacity within the Icelandic context.

\subsection{Administrative capacity}

Mouritzen and Svara (2002) argue that local government is based on three principles: professionalism, political leadership and the layman's rule. An ideal approach to the separation between politics and administration, based on the work of, among others, Woodrow Wilson (1887), views politics and administration as separate spheres, each with its clearly defined roles. Reforms inspired by new public management (NPM) have seen a revitalisation of these ideas (Kuhlmann \& Wollmann 2014). Others believe the relationship to be more complex, with the tasks and roles of elected officials and administration overlapping, as politicians engage in management and administrative staff in policymaking (Ejersbo \& Svara 2012; Kingdon 2003; Svara 1990). Thus, it may be argued that the role of professionalism is to uphold a functioning government. However, Kuhlmann, Veit and Bogumil (2015) argue that the qualification of the local public servants, as well as the structure of the personnel system, relies heavily on the functional responsibilities of the local government level. Simply put, different local types of government systems require different levels of expertise and numbers of staff within the local administration. Overall, the Nordic model is based on a high level of decentralisation, because the municipalities have numerous tasks and a broad range of responsibilities. The model also assumes a high level of professional capacity, although there are some variations to this rule (Baldersheim et al. 2017; Mouritzen 2010). Polidano (2000, 805) defines administrative capacity as 'the ability of the permanent machinery of government to implement policies, deliver services and provide policy advice to decision-makers'. Four topics 
of importance may be drawn from Polidano's definition. The first topic is connected to the 'ability of the permanent machinery', referring to the permanent local government administrative staff. These include issues relating to the number of administrative staff, the staff educational level, the question of whether to use a merit-based system or not and to the possibilities of job advancement. Similar approach may be found in Stone $(1993,17)$ who argues that 'technical capacity' may be enhanced through technical competence as well as the training and expertise of administrative staff.

The second topic is the 'implementation of policies', referring to the expertise of the local administrative staff and to the general ability of the administration to make independent decisions and organise tasks based on the knowledge and expertise of its staff. For example, Farazmand $(2004,6)$ argues that the administrative staff need to be highly qualified, able and motivated to tackle daily management problems in addition to making the strategic choices of tomorrow.

The third topic is the 'service provision', referring to the qualification and capacity of the local administration to provide quality service, thus indicating the so-called streetlevel bureaucrats.

Polidano's fourth and final topic is the 'provision of policy advice to decision-makers', which relates to the capacity of the administration to provide quality advice to local decision-makers, in this case, to the members of the local councils. Similarly, Lundtorp $(2000,6)$ puts emphasis on the role of leadership and argues that the administration must be able to demonstrate leadership and handle specialised tasks in a professional way.

Painter and Pierre (2005) further distinguish between three types of capacity: administrative capacity, policy capacity and state capacity. They claim that administrative capacity is, in its essence, about resource management. Moreover, it is the foundation for intelligent choice in policy-making that should lead to an appropriate outcome. Consequently, the capacity of a government to implement policy and produce a meaningful outcome is highly dependent on the level of its administrative capacity.

\subsection{Inter-municipal cooperation (IMC)}

One of the solutions to the alleged administrative capacity problem at the Icelandic local level has been to establish inter-municipal cooperation entities (IMC) or shared services. There are several ways to define shared services, the most basic one being to separate voluntary cooperation from compulsory cooperation and cooperation through incentives (Teles 2016). The main issue concerning the use of IMCs is the separation between the production and the provision of services (Dollery, Kortt, \& Drew 2016). In a nutshell, services are not necessarily provided by the municipality that is paying for them. Dollery, Kortt and Drew (2016, 229) refer to the seven Oakerson (1999) models when linking provision with production. These include: 'In-house production; coordinated production; joint production; inter-governmental contracting or outsourcing; franchising and vouchering. In addition to Oakerson's models, they also include services provided by volunteers to their list. These models may be further distinguished by the high or low level of institutionalisation and the soft or hard nature of cooperation 
(Teles 2016). Hulst and Montfort (2007) use a different approach when they separate between single and multi-purpose entities in addition to the form of cooperation. Unlike Dollery, Kortt and Drew (2016), Hulst and Montfort only have three models: formal agreements, policy networks and standing organisations. The choice of the production method is strongly linked to the administrative capacity as defined by Polidano (2000). There is an important difference between the administrative capacity of a municipality that chose in-house production versus the one that chose outsourcing or franchising, as the municipality in question must employ a minimum number of expert staff to be able to produce in-house services.

Inter-municipal cooperation is primarily meant to enhance the administrative capacity of the municipalities involved; in sum, the idea is that cooperation creates an added value. In this instance, the focus is on voluntary cooperation. An important feature here is the question of choice and the idea that IMCs provide the local authorities with the possibility to actively evaluate the costs and benefits of different service delivery choices (Eythórsson et al. 2018). In an addition to the models described above, Morse and Abernathy (2015) point out that there are numerous ways to organise the cooperation between local authorities. They also suggest that 'shared service arrangements vary greatly in their degree of actual service integration or consolidation' (p. 150). Hence, they separate between approaches based on fragmentation and consolidation in relation to the level of service provision and service production. Morse and Abernathy argue that there is a difference between the services organised in a collaborative way-for example by setting up a joint entity or co-owned agency with each municipality as an equal partner in the enterprise- and the cases where the function is transferred. In the case of function transfers, the municipality in question transfers the responsibility for the service provision to another municipality. Thus, a neighbouring municipality now takes over both the provision and production (see also Abernathy 2009).

Questions regarding the equality of partners in such schemes rise in cases of complex functional consolidation. This is especially important in cases in which the significance of the issue is much stronger for one partner than for the other (Morse \& Abernathy 2015). The same issues arise in cases in which the interests of different local authorities are likely to drift apart over time as more homogenous partners are more likely to be able to set up a well-functioning IMC entity (Feiock 2007; Klok, Boogers, Denters, \& Sanders 2018). This also touches upon the issue of the number of prospective partners; hence, a higher number of possible cooperation partners increases the number of IMCs, as does geographic proximity. Moreover, Dollery, Kortt and Drew (2016) argue that for 'small regional, rural and remote local authorities' (p. 228) the costs of setting up and running separate IMCs entities may prove too high, completely removing any IMC economic incentives. The final point to make is that there is also a tendency for IMCs to reproduce-as successful cooperation in one area leads to further cooperation. IMCs may expand by including more partners, taking on new policy area entities or increasing the intensity of cooperation in the original service area (Gendzwill \& Lackowska 2018). 


\section{Method and data collection}

Given the lack of basic information on inter-municipal cooperation in Iceland, the approach of this study is exploratory. ${ }^{2}$ One of the main issues in studying local government administrative capacity is deciding which local government staff belongs to the administration and which does not. The study focuses on three main tasks of local government: planning, education and social services in addition to the set-up of the core office. The research design chosen was that of a case study based on the most similar design (Yin 2008). By choosing only compulsory tasks, the likelihood of obtaining comparable data was increased. No differences were made between the staff members employed part-time and full-time. The aim was only to see if the staff members in these areas were present or absent. The chief executive of the municipality was not included in the number of staff.

The data collection took place from April to August in 2018. First, the data collection concentrated on in-house services. Local government websites were analysed, the number of experts in specific areas were counted and their titles were recorded. During this first round of data collection, all staff members situated in the city hall in relation to general management - or what is here referred to as the 'core office' and the three specific tasks listed above were identified and catalogued. Members of the core office have titles such as: book keeper, clerk, wage manager, financial manager or receptionist. Although these are not specialists in the same sense as a social worker, for example, their presence and numerousness provide important information about the bureaucratic strength of a local office. As the aim of this paper is to estimate the administrative capacity, only administrative members were counted and not street-level bureaucrats. For example, the principal of the local school is not included but the teaching advisor situated in the city hall is included in the list. In cases where the municipal websites did not give enough information, the local city halls were contacted directly. In cases where the experts were not situated in-house, information was collected about who provided the services.

Second, cases were identified in which the services for the three main task areas were provided externally through an IMC entity (co-owned agencies). Twelve such entities were identified and a questionnaire was sent via email to the managers of these entities to collect information about where the service was situated as well as in what way they were in contact with administrative staff and elected officials in the partner municipalities. Seven responses were received from the co-owned agencies.

Third, three semi-structured interviews were conducted with leading experts within the Icelandic Local Government Association regarding the three specific tasks. The main aim was to explore the type of information and assistance that the Association's experts are providing and whether this assistance is provided to administrative staff or local politicians alike.

During the time of data collection, changes were made because the number of municipalities decreased from 74 to 72 . In one case, two municipalities of similar size amalgamated into a new, large size municipality. As they were not finished with their restructuring at the time the study was conducted, this new municipality was left out of 
the analysis. In the other case, a small municipality merged with in comparison a very large one, having little noticeable effect on the number of office staff. The municipalities were grouped based on their number of residents as of January 1, 2018. Six equally sized groups were formed: 12 municipalities of up to 199 citizens; 13 municipalities of 200-499 citizens; 14 municipalities of 500-999 citizens; 14 municipalities of 1,0002,999 citizens; 11 municipalities of 3,000-9,999 citizens; and 7 municipalities with more than 10,000 citizens.

Due to extreme size difference, the seven largest municipalities with more than 10,000 citizens were left out of the study. The main reason for this is that all but one municipality is situated in the city region of Reykjavík and they are all completely selfsufficient in their service provision.

\section{Inter-municipal cooperation (ICM) in Iceland}

There is a long tradition of both voluntary and compulsory inter-municipal cooperation (IMC) in Iceland, either through individual municipalities or on a regional basis (Björnsson 1972). Originally, these IMCs were unregulated, however, in 1986, fundamental changes were made to the Icelandic Local Government Act (no. 8/1986), making one type of IMC mandatory for all municipalities. Previous systems had excepted the largest towns and cities from compulsory cooperation. These new, mandatory IMCs were called District Committees (is. Héraðsnefnd) and were mostly based on a previous regional cooperation system. The new District Committees were based on a system of joint production. They were never very popular and were formally abolished through the Local Government Act (no. 138/2011).

\subsection{The national associations}

The Icelandic Local Government Association or the Icelandic Association of Local Authorities is not an average IMC because it is an interest organisation for all municipalities by law. Membership is not mandatory even though every municipality was, in fact, a member in 2018. Their main source of funding is the Equalization Fund, which is to a large extent funded by the municipalities. The leading authority of the association is in collective wage agreements for local government staff. They also run an extensive service unit for the municipalities, advising them on everything from environmental issues to various legal matters.

\subsection{Co-owned agencies}

The 1986 Local Government Act (LGA) introduced a new type of IMC entity, the socalled co-owned agency (is. byggðasamlag), based on a Finnish model (Valsson 2014). The 'byggðasamlag' is traditionally the best-known type of IMC, as it is a formal entity with a strong legal basis in the Local Government Act. Local fire brigades, transport services and waste management are often organised through a co-owned agency. On a smaller bases, it is also common for two municipalities to create a co-owned agency to run a school. There is an independent board appointed by the councils and, usually, the 
municipal councils involved give the board administrative authority similar to that of the municipality (Valsson 2014). This is one of the reasons behind the criticism of the democratic deficit towards the co-owned agencies, as elected officials no longer have the authority or oversight over the service production funded by their tax-payers. Moreover, decision-making is based on majority rule and not on collective decision-making. Thus, decisions do not depend on all board members coming to an agreement. Another criticism of this type of an IMC is that the boards may become too independent and detached from the municipalities and that, de facto, the municipalities have no control over the boards. It is also often very complicated both financially and legally to withdraw from such cooperative projects. In the first large-scale study on Icelandic IMCs, Ragnarsson (2003) claims that the local councils preferred inter-governmental contracting over joint service production, such as that of co-owned agencies, because of these very problems. He also points out that, when the municipalities used inter-governmental contracting, they bought services either through a formal contract or in an informal way from another municipality or entered into contracts with private companies.

Overall, it is unusual for service barriers to be legally binding. The most notable example of such a barrier was found within the disability services, as there was a legal requirement that it had to be organised based on a minimum of 8,000 citizens. A new version of the law on disability services does not include this requirement any longer. Nevertheless, the majority of the services are still organised through the originally established IMC entities, although it is to be expected that some reorganisation will take place as a result of the new version of the law.

\subsection{Inter-municipal contracts}

The main problem with using agreements or contracts for inter-municipal cooperation was that, originally, the law did not explicitly state whether this practice was legal or not, creating a legal dilemma (Valsson 2014). Any doubt in this regard was removed in 2011 with the new LGA, which stated that municipalities are free to organise cooperation in any way they see fit as long as there are no legal barriers. The formal contracts are either used by small municipalities when buying services from larger municipalities (e.g. social services, educational services) or when buying technical services (computer services, cleaning, janitor services and snow ploughing) from private companies. It is, however, rare for municipalities to purchase 'people' services from private entities. An example of such practice is provided by the municipality of 'Tálknafjörður (consisting of around 250 inhabitants), in the Westfjords, which buys its school services from a private firm. The positive side of buying services through inter-governmental contracting is that there is no need for a board and therefore decision-making is easier and faster. However, when using this type of IMC, the municipality buying the services loses the legal protection that comes with the joint production set up of a co-owned agency as well as influence over how the services are organised and provided. This may become problematic if the service provider decides to cancel the contracts because, in many cases, the local governments have nowhere else to turn and are thus in a weak bargain- 
ing position. This problem has been identified in relation to very small or geographically isolated municipalities (Hlynsdóttir 2018b).

\subsection{The frequency of inter-municipal cooperation (IMC)}

The new LGA in 1986 set up a framework for the use of IMC. It has been argued that these changes made the system of numerous small municipalities permanent (Grétarsson 2013), because they allowed for the use of IMC in place of large-scale consolidation. An indicator of this is evident in a recent report on inter-municipal cooperation in Iceland (Eythórsson 2018; Jóhannesson, Jóhannesson, \& Eythórsson 2016). The study counted more than 300 IMC entities of various types of which the most common was inter-governmental contracting. This supports the findings of Ragnarson (2003), which show that the number of co-owned agencies has dwindled while contracts or agreements have been on the rise. Moreover, the IMC entities are most frequently found within the education and social services. Furthermore, they are usually organised as joint production units through single-purpose standing organisations. The second most common IMC is single-purpose inter-governmental contracting and the third most common is joint production through multi-purpose standing organisations.

One of the main issues in relation to IMCs is the lack of a clear hierarchy. Just as a clear hierarchy is the building block for accountability in public organisations, an unclear hierarchy brings with it obvious problems for identifying accountability (Bovens 2005). In the Icelandic context, hierarchical issues concerning IMCs have been identified as a source of democratic deficit (Kristinsson 2014). The transparent accountability of the principal-agent relationship between voters (principals) and council members (agents) is either diffused or lost. In relation to this, questions have been raised about how important these deficits really are in comparison to the benefits that IMCs bring to small municipalities.

In sum, the rule of thumb is that the Icelandic local authorities are free to organise their cooperation in any way they please unless otherwise stated by law (Valsson 2014). In addition, there are also indications of regional variations on how IMCs are chosen and arranged and studies have shown a tendency for path dependency (Sveinsson 2014). Thus, different traditions seem to apply to different areas when it comes to arranging inter-municipal cooperation.

\section{Results}

\subsection{The 'permanent machinery' of the Icelandic local administration}

The number of permanent staff members is the foundation for administrative capacity, as pointed out by Polidano (2000). Overall, the findings confirm earlier reports of a relatively low number of staff in the city halls of Icelandic municipalities (Hlynsdóttir 2016). A large majority of municipalities with less than 199 inhabitants have no public office and their staff usually only consists of the leader of the council, who is also the acting chief executive of the local authority. Due to the low number of staff members in this municipality group size, they are not included in Figure 1. 


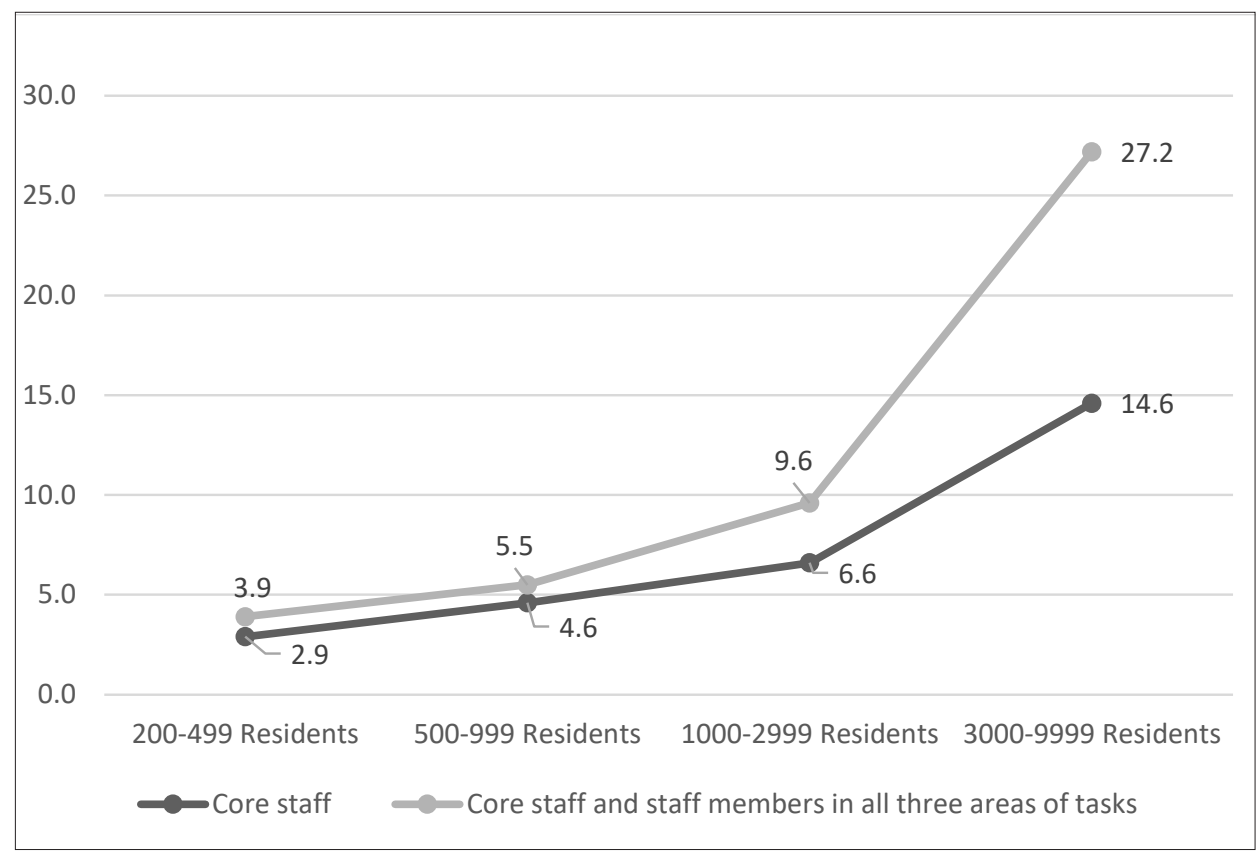

Figure 1. Average number of staff in core office compared to the overall number of staff in city hall

As is evident from Figure 1, the 200-499 inhabitant municipality group usually has a core office that consists of only one to two staff members in addition to the chief executive, commonly a bookkeeper or a wage officer. The average number of core staff is 2.9. Out of the 13 municipalities in this size group, four employ staff for social services and six in the area of planning and building, while there are no staff members listed in the area of education. In the majority of cases, the expert staff constituted one person, although in the area of planning there were two cases in which a municipality employed two individuals in the area of planning and building. This provides us with an average of 3.9 staff members in this group.

In the 500-999 citizen group, the number of the core staff members increases slightly, as the average core office here has 4.6 members in addition to the chief executive, ranging from two to eight. Out of the 14 municipalities in this group, two employ one person in the area of social services, while 10 municipalities employ staff for the task of planning and building permits. This gives us an average of 5.5 staff members for the core office and the three service areas.

The third group consists of 14 municipalities with 1,000-2,999 citizens. The average number of staff in the core office rises slightly to 6.6 members, while there is a considerable increase in the number of staff in the three respective service fields. Again, municipalities employ staff most frequently in the area of planning and building permits, with only two municipalities that have no staff in this area. Seven municipalities have experts 
in the area of social services, usually more than one. Only four municipalities have experts in the area of education in the city hall. The average number of staff members in the core office and the three service areas is now 9.6.

The last group in Figure 1 has a range of citizens from 3,000-9,999, out of which only two have more than 5,000 citizens. ${ }^{3}$ This group consists of 11 municipalities. As is evident from Figure 1, there is a huge difference in the number of staff members, both in the core office and in the specialised areas of education, social service and planning, from the other municipality size groups. On average, the core office has 14.6 members, ranging from 6 to 23 members, and the whole office has an average of 27.2 members. In addition to the typical core office staff mentioned above, there are now also financial managers, record managers and service representatives, who are often found in large numbers. For example, one municipality of 3,200 residents has 15 core office staff members in addition to the city manager. In the case of the more specialised staff, they are also more numerous. In addition to the building instructor, there are now planning specialists, construction engineers and specialised assistance personnel in the field of planning. There is usually more than one manager of social affairs, in addition to managers of education, teachers' advisors, several social workers, a psychologist and, in some cases, a speech pathologist, who are otherwise somewhat of a luxury. Lawyers or legal specialists are, however, very rare.

As evident from the above discussion, the relationship between the size of municipality and the number of staff in the city hall is not linear. There are many cases of municipalities having a disproportionally large or small number of staff in the city hall, especially in the larger municipalities. The first issue to point out is density as in population per area, because there is a correlation between the density and the number of staff in the city hall. The more compact the geographical size of the municipality, the lower the number of its staff. An example of this are towns such as Seltjarnanesbær (aprox. 4,500), which has 10 members in the core office, and Grindavíkurbær (aprox. 3,300), which has seven, in comparison with Norðurping (approx. 3,200), which has 16 members, and Fjarðarbyggð (aprox. 4,700), which has 14 staff members in its core staff. The main difference is that Seltjarnanesbær is geographically one of the smallest municipalities, while Norðurping is one of the largest. Another issue is that both Norðurping and Fjarðabyggð are relatively new municipalities, created through extensive amalgamation. This suggests that the government's aim to 'enhance' the administrative capacity of the local governments through amalgamation (Eythórsson 2012) may have been partly successful, as the municipalities with a history of large-scale amalgamation have a proportionally larger number of administrative staff in comparison to similarly sized municipalities without a history of amalgamation. However, this might also mean their administration is somewhat inflated because of geographical size.

Another point to make is that geography plays a significant role in what type of expertise is integrated into the city hall. Small municipalities in areas with a large number of tourists or popular destinations for second-home owners are more likely to employ planning experts than the local authorities in less dynamic areas. 
The last point that may be drawn from this discussion is the high concentration on the core staff in the city hall, as there is an enormous size difference between the municipalities with 1,000-2,999 citizens and the municipalities with more than 3,000 citizens. This suggests that the level of services provided by the office must increase along with the demand of coordination. On the other hand, it may be argued that the numbers of both core staff and of experts in the smaller municipalities do not represent the level of service provided to their citizens, as these municipalities tend to use intermunicipal cooperation for their services in an attempt to reach some kind of economy of scale (Teles 2016).

\subsection{The 'expertise' of local administrative staff in IMCs}

In relation to administrative capacity, Farazmand (2004) argues for a high level of qualification within the administration because this is the foundation for the administrative capacity to make independent decisions and organise tasks. An introduction of an IMC entity is believed to be able to fulfil some of these needs (Eythórsson 2018; Feiock 2007; Teles 2016). There were 12 joint entities or co-owned agencies identified for the tasks of education, social services and planning. As pointed out previously, this study only includes expert services; hence, schools set-up as co-owned agencies are not included. There is a clear pattern of specialisation and services in the municipalities studied. The largest municipalities, with more than 3,000 citizens, seem to be self-sufficient in their provision and production of services. These municipalities are rarely members of any of the identified standing organisations or co-owned agencies. The exception to that rule is their frequent presence in the standing organisations built around the provision of disability services, which is the result of the fact that, prior to the changes made to the law on disability services in 2018, the municipalities were obliged to create service areas of 8,000 citizens for disability services. Moreover, some of the agencies for disability services are set up only for fiscal redistribution and are not service producers.

Out of the 12 standing organisations identified, 11 are larger (more than three members). The region of Westfjord was the only region in which such standing organisations were practically not found and only one was identified. The region has only one large town with more than 3,000 inhabitants and is known for its large number of very small municipalities. Moreover, it is also known for being very sparsely populated with long distances and difficult road infrastructure. Interestingly, the municipalities in this region were also more likely to buy their services from private firms or through long-distance services. Dollery et al. (2016) claim that small municipalities in sparsely populated rural areas may find the administrative and overhead costs of setting up a standing organisation to be too costly. Another issue is proximity, as areas with higher population density and the possibility of several different potential IMC partners are more likely to have well-functioning IMC entities (Feiock 2007; Klok et al. 2018). This may explain why co-owned agencies are more often found in areas with high density, an example of this being the densely populated district of Árnessýsla in the south with several co-owned agencies. These agencies have a history of spill over, as cooperation started in one ser- 
vice area and has moved to another, as well as substantial growth of the number of individual partners (Gendzwill \& Lackowska 2018).

In relation to the development of IMCs in the area of education, social services and planning there are some clear trends. Experts in planning and building permits are the most likely experts to be found within individual city halls, closely followed by social workers. Experts in education are only found in municipalities with more than 1,000 citizens, while smaller municipalities obtain these services from elsewhere. Also, expertise in the area of planning and building is often bought from private firms, while services in education and social services are more often found in co-owned agencies. Simply put, individual local authorities like to have direct access to experts in planning and building, while expert services in the areas of social services and education are organised differently. This shows that there is a trend towards different tasks developing different levels of 'optimal' size, as small municipalities seem to be able to have their own staff in planning, while experts in social work and education require a larger tax base (Feiock 2007).

Another important factor is the size of the municipality. The smallest municipalities are heavily engaged in the 'transfer of functions' (Morse \& Abernathy 2015) because they permanently transfer the service production and provision to another municipality. Municipalities with less than 200 citizens are almost never found in any of the standing organisations and a larger bulk of their services in the three task areas of this study are provided through an inter-municipal contract with a larger neighbour. There are also examples of municipalities in these size groups that have outsourced their bookkeeping to a private accounting firm. Again, this touches upon the debate about the 'right' size of local government. Decentralisation is one of the foundations for the existence of local elected authorities (Sharpe 1970), however, it has also been pointed out that this brings forth problems for small municipalities (Vries 2000) as they are not able to handle the increase in administrative workload.

\subsection{The 'provision of policy advice to decision-makers'}

Administrative capacity also includes the ability of the local administration to provide policy advice to decision-makers (Polidano 2000). One of the main issues regarding the level of administrative capacity of small municipalities is the question of where they turn to if they are not able to draw on expertise from within their city halls. In the Icelandic case, the co-owned agencies, set-up separately to provide service in respective areas, may become a source of administrative expertise; the other possibility is that they turn to the machinery of the Local Government Association. Based on the answers of the managers of the co-owned agencies, they most frequently communicate with the chief executive, followed by the leading politicians, while the individual elected officials were less likely to approach the agency. The managers of co-owned agencies in the area of education and social services all confirmed that they had participated in the policymaking in individual municipal members of the standing organisation. This suggests that these experts are part of the inner machinery of the local government administra- 
tion to some extent, at least. This also suggests that there may be active mechanisms in action, preserving the chain of accountability (Bovens 2005), which is a problem often identified within the IMC set-up of standing organisations (Gendzwill \& Lackowska 2018; Teles 2016).

However, the Local Government Association seems to be an even more important source of expertise for the municipalities. The service of the Local Government Association is free for all municipalities and, as pointed out by one of the interviewees, the staff at the association need to take care not to provide 'too extensive services', as it seems that in many cases the local authorities find it easier to contact the association and get quick and free services than to buy them from a legal firm. There are several layers of services sought by the municipalities. First, there are staff members, such as social service or education service staff, who need assistance in organising services. Then, there are cases of issues over which disputes might arise, such as in the sphere of the disability services. The association staff also provide the municipalities with proofreading services in legal matters. Finally, the council members also contact the association, especially the members of the minority parties in the council, usually seeking guidance and help in interpreting the law in relation to legal guidelines for council meetings.

There are clear differences between the type of assistance provided for different municipality size groups. Overall, the experts at the Local Government Association provide smaller municipalities with more hands-on information, often assisting them in a very detailed and specific manner. One staff member stated during the interview that, 'we often get inquiry from municipalities with small administration, which we are able to answer quickly, issues they really should know the answer to'. One of the interviewees claimed that the municipalities with less than 3,000 citizens are more likely to have problems in dealing efficiently with their administrative tasks.

However, another interviewee also added that the tiny municipalities rarely contacted the association, suggesting that most of the work done by councils in these municipalities is repetitive work. As they buy all their services through inter-governmental contracts, all the organisation of services is conducted elsewhere. What most of these issues have in common is that the smaller municipalities need more hands-on assistance, while the larger ones are more often looking for assistance or guidelines in general policy making. Also, in the case of the smaller municipalities, the city manager is more often the one initiating contact, while senior managers are usually doing that in the larger municipalities. The findings from the interviews suggest that the decentralisation of tasks onto the local level is putting a heavy strain on the administration in the smaller communities. Given the frequency of contact with the experts from the Local Government Associations, this suggests that the established standing organisations, such as co-owned agencies, are only partly abled to strengthen the local administration. Thus, in relation to administrative capacity, the promises made by the advocates of inter-municipal cooperation may only be partially fulfilled (Eythórsson 2018; Feiock 2007; Teles 2016; Warner 2015). 


\section{Conclusion}

The Icelandic central government has successfully decentralised several important services onto the local level. Service provision in planning, education and social services is undoubtedly a local government task. As pointed out earlier, all municipalities are legally obliged to provide the same level of services but there are no specific guidelines on how this should be achieved. Therefore, the municipalities may produce services either inhouse or through inter-municipal cooperation. The aim of this paper was to attempt to estimate the capacity of the Icelandic local administrations for providing expert services in education, social services and planning, based on the size of their 'permanent administration' (Polidano 2000) and the scope of inter-municipal cooperation. Three research questions were used as guidelines.

The first question addressed how big the permanent machinery of the Icelandic local government administration is. There is no simple answer to that question, as the number of people employed in a city hall appears to be highly situation-dependent. However, the findings show that a large majority of municipalities have less than 10 people working within the city hall on the core office tasks and on expert services in planning, education and social service areas. It may be concluded that if the municipalities are supposed to be able to provide full services in these areas, then this number of staff is too low. However, it is also clear that many municipalities are able to compensate for the low number of staff in their city halls through extensive IMCs.

The second question looked at the types of expertise present in the city hall with respect to planning, education and social services. The findings show that experts in technical services, such as planning and building permits, are usually the first to be hired with social workers next in line. Experts in education are seldom found within the city hall. In some cases, parts of these services may be stationed within the schools themselves; however, it seems that a normal approach is to establish a standing organisation for these services, which are then coordinated on a large geographical scale. In the core office, there is usually a bookkeeper, a receptionist or a wage manager in addition to the chief executive. Experts in fiscal management are usually only found in the larger municipalities.

The final question was related to how the municipalities compensate if their city halls are lacking in expert staff. The findings show that the local authorities turn to standing organisations for expertise, however, the main source of expertise seems to be the Local Government Association. While the big municipalities seek assistance with long-term policy-making, the smaller municipalities are more likely to look for hands-on assistance for daily tasks of the local administration. However, the very small municipalities contact the Local Government Association only rarely, suggesting an extensive level of transfer of daily tasks to other municipalities.

This study represents only a first attempt to estimate the level of administrative capacity at the local level in Iceland. The findings suggest a low level of local administrative capacity in the majority of municipalities. Although is not possible to draw any conclusions based on this study about the quality of the service provision, it must be 
pointed out that administrative capacity is fundamental for effective local governance as it lays the foundation for the provision of quality service.

\section{Acknowledgements}

This study was funded by the University of Iceland Research Fund.

\section{Notes}

1 Only small parts of services to elderly citizens are the responsibility of the municipalities, thus 'social services' represent only services provided by the municipal level.

2 An exception is the report by Jóhannesson, A.P., Jóhannesson, H., and Eythórsson, G.T. (2016) and the article based on it by Eythórsson (2018).

3 If these two municipalities are excluded the average drops from 27.2 down to 24.6.

\section{References}

Abernathy, C.R. (2009). Service Delivery Consolidation, Governance and the Enhancement of Local Government Capacity: Creating a Service Consolidation Model (PhD dissertation). Retrieved from http://trace.tennessee.edu/utk_graddiss/5/

Askim, J., Klausen, J.E., Vabo, S.I., and Bjurstrom, K. (2016). "What Causes Municipal Amalgamation Reform? Rational Explanations Meet Western European Experiences, 2004-2013”, in S. Kuhlmann and G. Bouckaert (eds.), Local Public Sector Reforms in Times of Crisis: National Trajectories and International Comparisons (pp. 59-80). London: Palgrave Macmillan.

Baldersheim, H., and Rose, L.E. (2010). "Territorial Choice: Rescaling Governance in European States", in H. Baldersheim and L.E. Rose (eds.), Territorial Choice: The Politics of Boundaries and Borders (pp. 1-20). London: Palgrave Macmillan.

Baldersheim, H., Rose, L.E., and Sandberg, S. (2017). "Local and Regional Government in the Nordic Countries: Co-Operative Decentralization", in O. Knutsen (ed.), The Nordic Models in Political Science: Challenged but Still Viable? (pp. 193-218). Oslo: Fagbokforlaget.

Bel, G., and Gradus, R. (2018). "Privatisation, contracting-out and inter-municipal cooperation: New developments in local public service delivery", Local Government Studies 44(1), 11-21. https:/ / doi.or $\mathrm{g} / 10.1080 / 03003930.2017 .1403904$

Björnsson, L. (1972). Saga sveitarstjórnar á Íslandi sídara bindi. Reykjavík: Samband íslenskra sveitarfélaga.

Bovens, M. (2005). "Public Accountability", in E. Ferlie, L.E. Lynn Jr., and C. Pollitt (eds.), The Oxford Handbook of Public Management. Oxford: Oxford University Press.

Denters, B., Goldsmith, M., Ladner, A., Mouritzen, P.E., and Rose, L.E. (2014). Size and Local Democracy. Cheltenham: Edward Elgar Publishing Ltd.

Dollery, B., Kortt, M.A., and Drew, J. (2016). "Fostering shared services in local government: A common service model", Australasian Journal of Regional Studies 22(2), 225-242.

Ejersbo, N., and Svara, J.H. (2012). "Bureaucracy and Democracy in Local Government", in K. Mossberger, S.E. Clarke and P. John (eds.), The Oxford Handbook of Urban Politics (pp. 152-178). Oxford: Oxford University Press.

Eythórsson, G.T. (2012). "Efling íslenska sveitarstjórnarstigsins: Hugmyndir og aðgerðir” [Reinforcing the Municipal Level in Iceland: Ideas, Policies and Implementations], Icelandic Review of Politics \& Administration 8(2). Retrieved from http://www.irpa.is/article/view/1187/pdf_278

Eythórsson, G.T. (2014). "Sameining sveitarfélaga á Íslandi í 70 ár. Röksemdir sameiningarsinna og andstæðinga" [Efficiency, Capacity and Democratic Deficits. Arguments for and Against Municipal Amalgamations in Iceland for 70 Years], Icelandic Review of Politics \& Administration 10(1), 143-168. Retrieved from http://www.irpa.is/article/view/1326

Eythórsson, G.T. (2018). “Bigger and Stronger Together: How Icelandic Municipalities Solve their Lack 
of Capacity and Scale Economy", in F. Teles and P. Swianiewicz (eds.), Inter-Municipal Cooperation in Europe: Institutions and Governance (pp. 209-224). Palgrave Macmillan.

Eythórsson, G.T., Kettunen, P., Klausen, J.E., and Sandberg, S. (2018). "Reasons for Inter-Municipal Cooperation: A Comparative Analysis of Finland, Iceland and Norway", in F. Teles and P. Swianiewicz (eds.), Inter-Municipal Cooperation in Europe: Institutions and Governance (pp. 105-130). Palgrave Macmillan.

Feiock, R.C. (2007). "Rational Choice and Regional Governance”, Journal of Urban Affairs 29 (1), 47-63. Gendzwill, A., and Lackowska, M. (2018). "A Borrowed Mandate? Democratic Legitimacy of Intermunicipal Entities: A Comparative Analysis", in F. Teles and P. Swianiewicz (eds.), Inter-Municipal Cooperation in Europe: Institutions and Governance (pp. 57-78). Palgrave Macmillan.

Grétarsson, I.E. (2013). Sveitarfélög á Íslandi 1872-2012: Forsaga lagabreytinga og ferli endurskodunar (MPA thesis). University of Iceland.

Hlynsdóttir, E.M. (2016). "Administrative capacity and long-term policy making at the Icelandic local level", Icelandic Review of Politics \& Administration 12(2), 237-258. https://doi.org/10.13177/ irpa.a.2016.12.2.3

Hlynsdóttir, E.M. (2018a). "Autonomy or integration: Historical analysis of the debate on the purpose of Icelandic local self-government", Icelandic Review of Politics \& Administration (Special Issue on Power and Democracy in Iceland), 83-100.

Hlynsdóttir, E.M. (2018b). "Can Tiny Municipalities Survive Through Extensive IMC Arrangements? The Case of Iceland”, in F. Teles and P. Swianiewicz (eds.), Inter-Municipal Cooperation in Europe: Institutions and Governance (pp. 327-332). Palgrave Macmillan.

Hulst, R., and Montfort, A. van. (2007). "Comparative Analysis and Conclusions", in R. Hulst and A. van Montfort (eds.), Inter-Municipal Cooperation in Europe (pp. 211-230). Dordrecht: Springer Publishing Company.

Jóhannesson, A.P., Jóhannesson, H., and Eythórsson, G.T. (2016). Samstarfsverkefni sveitarfélaga. Retrieved from https://www.rha.is/static/files/Rannsoknir/2016/samstarf_sveitarfelaga_lokaskyrsla.pdf

Kingdon, J.W. (2003). Agendas, Alternatives, and Public Policies (2 ${ }^{\text {nd }}$ ed.). New York: Longman.

Klok, P.-J., Boogers, M., Denters, B., and Sanders, M. (2018). "Inter-municipal Cooperation in the Netherlands", in F. Teles and P. Swianiewicz (eds.), Inter-Municipal Cooperation in Europe: Institutions and Governance (pp. 157-172). Palgrave Macmillan.

Kristinsson, G.H. (1994). Embattismenn og stjórnmálamenn: Skipulag og vinnubrögð i islenskeri stjórnsýslu. Reykjavík: Heimskringla.

Kristinsson, G.H. (2001). Staðbundin stjórnmál: Markmið og árangur sveitarfélaga. Reykjavík: Háskólaútgáfan.

Kristinsson, G.H. (2014). Hin mörgu andlit lýdrađis: Dátttaka og vald á sveitarstjórnarstiginu. Reykjavík: Háskólaútgáfan.

Kuhlmann, S., and Bouckaert, G. (2016). Local Public Sector Reforms in Times of Crisis: National Trajectories and International Comparisons. Palgrave Macmillan.

Kuhlmann, S., Veit, S., and Bogumil, J. (2015). "Public Service Systems at Subnational and Local Levels of Government: A British-German-French Comparison”, in F.M. van der Meer, J.C.N. Raadschelders, and T.A.J. Toonen (eds.), Comparative Civil Service Systems in the 21st Century (2nd ed.) (pp. 162-184). Palgrave Macmillan.

Kuhlmann, S., and Wollmann, H. (2014). Introduction to Comparative Public Administration: Administrative Systems and Reforms in Europe. Cheltenham: Edward Elgar Publishing Ltd.

Local Government Act no. 138/2011.

Morse, R.S., and Abernathy, C.R. (2015). "Mapping the Shared Services Landscape", in A.C. Henderson (ed.), Municipal Shared Services and Consolidation: A Public Solutions Handbook (pp. 143-160). New York: Routledge.

Mouritzen, P.E. (2010). "The Danish Revolution in Local Government", in H. Baldersheim and L.E. Rose (eds.), Territorial Choice: The Politics of Boundaries and Borders (pp. 21-41). Basingstoke: Palgrave Macmillan. 


\section{STJÓRNSÝSLA}

Mouritzen, P.E., and Svara, J.H. (2002). Leadership at the Apex: Politicians and Administrators in Western Local Governments. Pittsburgh: Pittsburgh University Press.

Painter, M., and Pierre, J. (2005). "Unpacking Policy Capacity: Issues and Themes", in M. Painter and J. Pierre (eds.), Challenges to State Policy Capacity: Global Trends and Comparative Perspectives (pp. 1-18). Palgrave Macmillan.

Polidano, C. (2000). "Measuring Public Sector Capacity", World Development 28(5), 805-822. https:/ / doi. org/10.1016/S0305-750X(99)00158-8

Ragnarsson, R. (2003). Samvinna sveitarfélaga á Íslandi: Valkostur við sameiningu? (MA thesis). University of Iceland.

Sharpe, L.J. (1970). “Theories and Values of Local Government”, Political Studies 18(2), 153-174.

Svara, J.H. (1990). Official Leadership in the City: Patterns of Conflict and Cooperation. Oxford: Oxford University Press.

Sveinsson, D. (2014). Samstarf sveitarfélaga á Vestjördum og á Nordurlandi vestra. Ábrif samstarfs á lýdradi og hagkvamni i rekstri sveitarfélaga (MPA thesis). University of Iceland.

Tavares, A.F. (2017). "Ten years after: Revisiting the determinants of the adoption of municipal corporations for local service delivery", Local Government Studies 43(5), 697-706. https://doi.org/10.1080 /03003930.2017.1356723

Teles, F. (2016). Local Governance and Inter-Municipal Cooperation. Basingstoke: Palgrave Macmillan.

Valsson, T.F. (2014). Sveitarstjórnarréttur. Reykjavík: Codex.

Vries, M.S. de. (2000). "The rise and fall of decentralization: A comparative analysis of arguments and practices in European countries", European Journal of Political Research 38(2), 193-224. https://doi. org/10.1023/A:1007149327245

Warner, M.E. (2015). "Municipal Size, Resources, and Efficiency: Theoretical Bases for Shared Services and Consolidation", in A.C. Henderson (ed.), Municipal Shared Services and Consolidation: A Public Solutions Handbook (pp. 3-16). New York: Routledge.

Wilson, W. (1887). “The Study of Administration”, Political Science Quarterly 2(2), 197-222. Retrieved from http://dmc122011.delmar.edu/socsci/politicalsci.html

Yin, R.K. (2008). Case Study Research: Design and Methods (Applied Social Research Methods). Thousand Oaks, CA: SAGE Publications Inc. 
